\title{
Migrant precarity and religious individualisation
}

\section{Introduction}

This chapter examines social processes of religious self-making and self-reflection in the context of precarious social and cultural encounters associated with global migration. More specifically, I examine the everyday life of Sikh asylum seekers who have left the Indian border region of Punjab since the political upheavals in the 1980s and 90s to seek asylum in Germany. When compared to the situation of Ahmadi Muslims discussed in my second contribution to this publication, the success rate of Sikhs in asylum hearings was significantly lower. The reasons for this were that, on the one hand, the category of 'religious persecution' was not applied to their situation while, on the other, the state, with striking parallels to current discussions about deporting young male refugees, suspected Sikh migrants to be supporters of militancy. For the Sikh individuals who I encountered in the period between 2003 and 2013, the suspension of rights and the general uncertainty they experienced demanded various adaptation strategies as well as the ability to manoeuver through social and legal grey zones for prolonged periods of time. My analytic work in this chapter pays close attention to how refugees caught in these social and legal grey zones articulate aspects of the religious self. The dialogues below advance ideas about how such a self is expressed through individual conduct and forms of agency that are not scripted by the standard vocabularies of religious norms or ideologically charged faith talk. The ability of these individuals to act and make sense of the world around them is mediated by the fact that their own religiosity is politicised as a consequence of their social isolation by highly individualising tendencies. When highlighting aspects of self-making and self-reflexivity in this context, I aim to illuminate how socio-legal processes of exclusion intersect with emergent ideas of how to be Sikh. In more abstract terms, I discuss ontological conditions of 'diasporic displacement' (Bakare-Yusuf

\footnotetext{
Note: This is a fully amended version of an earlier published chapter titled 'Religious Subjectivity in Spaces of the Otherwise' originally appearing in my book The Precarious Diasporas of Sikh and Ahmadiyya Generations with Palgrave Macmillan (2016). The German Research Council (SFB 619) as well as the Canadian Council for the Humanities and Social Sciences provided generous support for this project in addition to minor grants by the Faculty of Liberal Arts and Professional Studies, York University. I use pseudonyms throughout this chapter to refer to all of my research participants.
} 
2008) that are multifaceted and not reducible to established representations of Sikh religious identity or prevalent claims to tradition, even as elements of Sikh tradition remain a source for articulating sentiments of togetherness, suffering, and resilience. ${ }^{1}$

The relationship between migrant precarity and religion as discussed below is an issue of much wider scope than can possibly be covered by this small qualitative case study. What my case study can perhaps accomplish is a charting out of the realm of the ordinary (see Das 2007) that, because of its presumed historically inconsequential dimension, is often glossed over in political and sociological analysis. As this section's emphasis is on new possibilities of religious expression and new options for its realisation, it seems beneficial to trace such possibilities in ordinary language and with regard to the experiences of ordinary people at the social margins. I gesture here towards emergent life worlds and words that oscillate between everydayness and spontaneous articulations. I think about those who, feeling wasted, continue to labour and reach out to others even as they are abandoned by loved ones and about how they still find themselves in a creative process of forging relationships and relatedness to the world. We could say that they are forced to do so but they are also committed to something that lies elsewhere and that something goes beyond the need for wellbeing in conditions of depravity. As soon as we pay attention to people-on-the-move who face the material conditions of socio-legal exclusion, social marginality, and the difficult process of recovering memories of loss and violence, precarity becomes a concept loaded with heavy and often contradictory meanings.

Precarity is a term that circulates widely in public discourses today. It points to social vulnerability, the loss of income security as well as the curbing of individual rights and forms of human dignity. Whereas Standing (2011) and others have understood precarity in terms of a systemic change characterising global capitalism and, hence, the (demise of the traditional) working class more generally speaking, sociologists working on migrant precarity have emphasised the 'hyper-precarization' (Lewis, Waite 2015) of migrant labour resulting from the combined workings of de-regulated, low-wage sectors and the exclusionary mechanisms of state institutions that curb free movement. In the light of the massive uprooting of people and the emergence of growing refugee movements

1 When it comes to the social and political contexts of contemporary diaspora formations, I refrain from positing a deterministic corporeal scheme of loss and self-fragmentation, inasmuch as I resist celebrating a model of 'the diasporic' to capture a purely discursive form of selfreflexivity. However, I cannot explore here the complex histories of capitalist labour, migration and state violence in which much of the contemporary forms of Punjabi migration are rooted (see Nijhawan 2016). 
globally, sociologists have further challenged common categorizations of illegality and quasi-legality as these, in the words of one prominent author in the field, 'do not adequately capture the grey areas experienced by many migrants' (Gonzales 2011, 605). The extant literature provides a sound critique of the political economy of migrant precarity and the ways in which those deemed 'inadmissible' and 'illegal' face exclusion, if not an outright denial of their social identities. But inasmuch as these grey areas affect how migrants struggle in their everyday lives, it is within such scenes of fragmentation, and often devastation, that people realise potentials to creatively re-imagine their sense of (religious) self, person, and agency as a way of surviving, coping, enduring, and showing resilience. I thus wonder how we might look at the relationship between precarity, diasporic displacement and religious belonging.

Courtney Bender (2003) suggests that one way of tracing the meaningmaking processes of such a tenuous relationship is by paying attention to recurring genres and speech patterns that illuminate how in ethnographic encounters social actors articulate the generally fluid and often ephemeral concepts of 'the religious' in their interactions with others in specific social and institutional settings. This is not just about the actual words and how they might register in an established religious vocabulary, which might or might not be part of the equation. More importantly, we need to pay attention to how concepts acquire specific form, meaning, and affective layers, which in contexts defined by precarity occurs in particularly nuanced ways. The strength of the ethnographic encounter is to make visible this emerging sense of what we can understand and agree upon as the common ground of our relationships. It can contribute to an understanding of how we perceive our differences and how those differences are actually constituted, and, finally, of how we make sense of words and things that might seem evidently 'secular' or 'religious' in connotation and yet we cannot just assume to be transparent.

I read the voices below in how they lend themselves to such an emerging sense of (religious) subjectivity; that is, for how they become embedded in unfolding relationships in which claims to belonging are of existential concern. This does not amount to idealising the ethnographic encounter. Ethnography, understood here as a critical praxis of theorising cultural articulations, translations and encounters, lends itself to a contextualised understanding of what religious individualisation might entail, much in the way Martin Fuchs (2015) has delineated it. Ethnography nonetheless bears its own ethical and political challenges and is thus not offered as a methodological blueprint here. Living under precarious conditions entails that the very horizon of interpretation and social interactions involves a careful process of negotiating positionality and of assuring mutual trust, commitment, reliability, and sincerity. 
Consider for example the following interaction involving Harjeet Singh, one of the interlocutors we meet again later, and my research collaborator Khushwant Singh. ${ }^{2}$ As we were cautious in our initial tape-recorded interviews about how to address the everyday struggles and hardships around migrant precarity, we had asked Harjeet about his thoughts on participating in (tape-recorded) interviews. This is how he responded:

'I will talk about my personal opinion', Harjeet said, 'There is a reason why someone does something. Like when I came to Frankfurt from Limburg today, there was a reason for it. Each person has a way of thinking. That is a personal thing. And if you want me to talk about that, it will be from a personal point of view talking about my conditions only. And it is something else if you want me to talk about the field in general, Punjab's condition, like the percentage of Sikhs coming because of all the difficulties, and how many are coming because of other reasons. So what do you want me to talk about?'

'First tell us on a general level, what your insights are about the conditions to migrate', we inquired.

'Do not mind what I am saying, it is my personal opinion about coming here. For about the last three years, the Sikh parties here have approached me about a dozen times, asking me to join them. Even the good leaders have asked that I join their parties. But I personally feel that, being a Sikh, this is my own mission, it is my own struggle (larai), which I have to fight myself, alone. There are many things that I have kept to myself. My cousins probably don't even know about this, why all of a sudden I left all my work and life there. Even my girlfriend asked me what was the main reason for coming here. "What should I think about why you have come? Do you really have a problem there?" Sometimes, when I don't feel like speaking about it, I just stay quiet. You might pose a question that to answer truthfully would put me in trouble, so in that case I would not answer because I cannot lie. And if you have to answer, then answer truthfully because I do not lie. So if a question of yours could cause harm (nuksan), I might not be able to answer. With regard to turning the tape recorder on or off, I think trust is bigger than anything else. When you trust, and you give everything you have, then inevitably there can be damage. But one day you will get ten times the reward because there is one thing that is in all human beings, which makes the whole world work, what sustains our relationships (nirbah), you can also think of God $(\mathrm{rab})$ or if you think differently, you can call it a system. The one who is running the system, whoever he is, he always does justice, when the time is right. And you are the second person maybe, I told my girl friend the first time, she had asked me the same thing. I had told her that until now my answer has always been that, "I cannot talk about this". And because you have come into my personal life, later on you might not like me being quiet, and I do not lie, so listen to what I have to say carefully if you want to hear the story. And it is the same with you that I can live peacefully even without having to say anything. There is no pressure on me. Yet I feel that since you are going to do a good deed, then maybe I can contribute a little bit to it. I will find happiness in this.'

2 Interview conducted February 7, 2004 Frankfurt a.M. 
Harjeet employed the term nuksan frequently in this segment, but he used it with strikingly different connotations. He clearly recognised the danger of damaged social relationships in our research context and contemplated on the potential harm of being exposed as a person with insecure status. He also switched between different ethical and theological concepts, from using rab (a name for the divine that is more common in devotional movements) to terms such as nirbah, which evokes key tenets of the Sikh Guru's hymns, to repeating English loan words ('system') that invite an immanent frame of deliberating on ethical responsibility. Damage is a real threat and yet the encounter was seen as a potential to open horizons, as a possibility of togetherness, of making friendship even, and of understanding the world better and making sense of the prevailing situation. It had to be clearly articulated that our desire to know entailed a responsibility to respond - framed in terms of the damage it could do to relationships and the reality of a broader 'system of justice' that he evoked. We had spoken many times before about issues surrounding Sikh institutions and Sikh teachings with Harjeet, so he did express here a sense of moral obligation too. Such claims were a common thread in conversations that pertained to specific aspects of the social worlds of precarity, which often have to remain under the radar of public visibility and recognition.

Anthropologist Elisabeth Povinelli (2011) was concerned with this issue, asking how we might imagine alternative social projects and ways of life through the capacity to endure the structural violence of 'late liberal modernity'. ${ }^{3}$ More specifically, she tells us something about relationships to place and what she holds to be the more ambivalent question of one's embodied commitment (ibid., 112) in situations in which one is exposed to forms of chronic depravity and suffering. She poses these questions in the context of her longstanding ethnographic work with indigenous peoples in Australia. Not unlike other settler states, Australia's policy towards indigenous populations has been characterised by neoliberal restructuring enacted through massive economic projects, such as mining, but also through the legal and bureaucratic technologies of managing indigenous affairs and an official policy of recognition. The latter, couched in the language of benign intervention, has turned indigenous life into the object

3 Povinelli's use of 'late liberalism' is directly linked to the neoliberal project of the 'governance of the prior' (ibid., 34). By that she means the technologies of sovereignty that are built upon a scheme of cultural recognition through which settler state violence becomes intelligible and, in the eyes of the state, legitimised. Both liberalism and settler colonialism are, for her, diasporic objects as well (ibid., 38), which means that rather than there being a singular logic of the 'governance of the prior' in the context of settler states, there is an uneven dispersal of how these principles apply to those affected by land theft, land treaty and genocide. 
of the managerial order and made it subject to the regulative norms set up by the settler state. At the same time however, when speaking about potentiality and the capacity to endure in contexts of other alternative social and religious movements, she advances the question of where to locate the ability to endure and the will to persevere. Her work as ethnographer is placed firmly within this specific situation. When thinking about such forms of endurance, she doesn't slip into the resistance narrative of the 'weapons of the weak'. Instead she points at a recursive relationship between corporeality and carnality. ${ }^{4}$ This relationship is meant as a corrective to the current social theoretical trend of seeing all material formations in terms of their elasticity or plasticity. Povinelli instead wants to speak to and about indigenous ontologies in a way that accounts for social change and alterity, particularly for those who have to struggle in their everyday lives with conditions of fixation, immobilisation, precarisation, and bodily disintegration. ${ }^{5}$ Let me quote one of her paragraphs to illustrate this:

To what are we committing ourselves if we commit to a freedom that is the undefined and undefinable trajectory of a radical otherwise in our world's scenes of abandonment? This otherwise may lie in shattering the life-world in which a person finds herself situated, but it also might mean maintaining a life-world under constant threat of being saturated by the rhythms and meanings of another. The conditions of excess always sit side by side with conditions of exhaustion and endurance that put into question the neat capture of substance by capital and other biopolitical projects and complicates the simple ethical investment in the thresholds and transitions of becoming within biopolitics. In these situations, to be the same, to be durative, may be as emancipatory as to be transitive. To live the present as if it were this future demands that a social world learn how to maneuver illegally. Those who must hide out within this environment, appearing to be in a time they are not even as they must go on heightened alert because the time they are in is a time no one wants to recognize.

(ibid., 130)

In what follows below, I want to explore the durative aspects of spatiotemporal processes, emphasising the embodied dimension of social worlds in which one maintains an existence. I see the circumstances of my Sikh interlocutors as being defined precisely by this durative quality. It is expressed through many everyday references and idioms. This process is discursively over-determined by the language of legal toleration and the sheer inaccessibility to the public realm of debating cultural

\footnotetext{
4 Corporality is understood by Povinelli as 'the discursive construction of materiality' or 'the arts of material formation' (ibid., 108-9), whereas carnality is defined as 'the unintegrated, errant aspect of materiality' (ibid., 109) or the spill-over effects that cannot be reintegrated into the order of things.

5 Note that Povinelli speaks of the ordinary in ways that distinguish how people are situated in late liberalism so that for some the ordinary becomes generalisable whereas for others it does not. 'We can think of the ordinary as the local spacing of eventfulness' (ibid., 133).
} 
citizenship. In our conversations, each of my interlocutors articulated their relationship to the teachings of the Sikh Gurus as an evolving effort and commitment, something that is never finished but requires an everyday labour on the self.

Experts in Sikh philosophy have underscored the non-dualistic configuration of the Sikh self (Singh 2003; 2014; Mandair 2009). Commenting on key texts in the Guru Granth Sahib such as the Japji (one of Nanak's key compositions), they emphasise how attributes that are associated with the ego-self in its desires to draw boundaries between the ego and the other and its preoccupation with all kinds of repetition in the form of 'concepts, rituals, or austerities' (Mandair 2009, 370) ultimately work, in the words of the Sikh Gurus, as impediments to realising a state of mind-being referred to as gurmukh. Paradoxically, argues Arvind Mandair, while in Sikh thought, 'the ego might be the problem [...] the solution to the problem also lies in [how we understand] the constitution of the ego' (ibid., 370). He goes on to explain the specific facets of this ego-problem that have been addressed by the Sikh Gurus. One aspect is that which causes the separation or duality when we project qualities onto another, whereas one's own cherished qualities 'become the basis for normative reality' (ibid., 371). With Lacan, Mandair explains this as a psychic mechanism that singles out aspects of the self that, as estranged and separated parts, are then projected outwards as attributes to which we must remain attached. This affective process instils a norm of what is good, cherished, desired and, thus, implicitly leads to a self-affirmation by repetitively 'solidifying our experience of the temporal world' (ibid., 371).

How does one struggle with such inherited concepts of ego-loss and the non-dualistic self when at the same time the attachment to material realities and the daily encounter of conditions of alienation arrive through a particular set of forces and social obligations from which distancing oneself does not appear to be a realistic option? I address this question in the subsequent sections on 'sangat' (congregation), 'dukkh' (suffering), and 'charhdi kala' (resilient ethos) in which we encounter individuals who engage in practices of learned spontaneity that defy the biopolitical projects of citizenship and belonging. Whether these take the form of re-inhabiting scenes of abandonment and concepts of spirituality that must remain under the radar of legal recognition, as Povinelli suggested, or emphasise a relationship to community under conditions of social and legal precarity, each scenario suggests a durative practice that keeps the self open to modes of alterity. A Sikh self engages here that struggles with the social and economic realities of the world in pragmatic ways without adhering to "narcissistic self-love' (Mandair 2009, 377). This is not about utopian counter models, nor do I want to gloss over the differences between notions of sacrificial love (ego-loss) engendered in Mandair's readings of Nanak and Povinelli's attempt to think love within the framework of immanent critique as she distances herself from the 
sacrificial norm (with regard to nationalism, a concept that is rejected by Mandair too). The key point is that 'being for another' in Sikh ethical thought engenders the image of a non-dualistic self that requires a durative quality: not in the sense of an identity that is upheld, but rather in terms of an aesthetic-meditative-social practice of other-relatedness. This construction of the self echoes a different temporality from that produced by the politico-economic order. Hence, I situate interlocutors somewhere between the two scenes captured above. As sojourners who strive to stay committed to the principles of gurmat and of becoming gurmukh, their orientations to place and existence carry something into their narratives on contemporary forms of exclusion and the specific diasporic conditions they face (that is, the forces that potentially erode the very conditions from which creative praxis might originate). The commitment to withhold and 'stay the same' in such scenes is a difficult achievement that requires both an unconscious and conscious effort to resist the 'rhythms and meanings of another' (Povinelli) so as to avoid complete fragmentation or the usurpation by powerful normative regimes. Povinelli's idioms of 'hiding out' and 'manoeuvring illegality' are closely related to my own exploration of 'precarious diasporas' (Nijhawan 2016), for those captured in their commitments to place, space and religion are always engaged in specific acts - acts of inaugurating relationships and acts that differentiate and subvert the social and political field of belonging.

\section{Sangat: discourses on maintaining self-integrity}

The term sangat carries historical weight and depth for Sikhs and is one of those long-established terms for which one finds widely used definitions. A sangat or congregation would originally form around the historical figure of a Sikh Guru, from Nanak in the late fifteenth century to Gobind Singh in the early eighteenth century. This memory is relived in the manner in which activities are organised around the Adi Granth (Guru incorporated in the 'book'), like the sung repetition and bringing to life of the Guru's bani (speech, hymns). Sangats are always evaluated in dimensions other than mere face-to-face relationships. Being a member of a sangat also entails, for many, being on a spiritual trajectory for which the language of the Sikh Gurus offers the concept of the sat-sang, an emergent sense of a sangat that is better understood in temporal rather than spatial dimensions (Mandair 2009, 31). However, as mentioned above, such terms acquire very specific meanings when seen in social practice. Let me explore this with Harjeet Singh's voice, as I have spent many hours with him debating issues pertaining 
to the lived sociality in and around the Sikh gurdwara. His frequent references to sangat indicated to me shifts between a more individualist approach and moral commentaries on the erosion of collective values.

In our interviews and informal conversations, as indicated above, he often rebuked the approaches by different parties at the gurdwara to join their ranks and he instead referred to Sikhi as 'his own mission'. ${ }^{6}$ In doing so, he did not reject being part of a congregation but, rather, reclaimed a notion of sangat on the basis of specific participatory engagements that allowed him a sense of autonomy in this togetherness. In other words, he did not rule out the networked social group that forms a sangat but rather considered his struggle in relation to it. Sangat was certainly seen to be built on a set of shared commitments, values and cultural ideas, but what comes to the fore in his colloquial speech is a kind of self-reflexivity that repeatedly juxtaposes socio-spatial aspects of how a particular sangat has been formed with his own quest for religious becoming.

For example, Harjeet deliberated on the specific conditions facing a sangat here and elsewhere. Drawing on such differences became a way of asserting his current position, of reassuring himself of the meaningfulness of what he did on a day-to-day basis as he then still lived with uncertain status. There were all the lingering doubts about having left his mother and siblings behind, as the prospect of contributing to livelihood through remittances and other socioeconomic transactions had been curtailed by the conditions of the precariousness he endured: work permits were either temporary or not granted for prolonged periods and movement was bureaucratically restricted by the visa-issuing office. Thinking about and comparing different sangats thus facilitated the ordering of memories and moral as well as political judgments. His reflections were triggered by social interactions and transactions in the present, for he clearly felt trapped in unhappy circumstances and difficulties. Harjeet said: 'There are some real difficulties here. In Punjab for example, you can go to the gurdwara freely [...]; here the conversation is always about legal and illegal. Over there anyone can come and live with the sangat [...] but here you cannot keep too many in the gurdwara, because if you do, then you have to figure out who has their papers or not.'

The circular movement of people, things and ideas along transnational routes becomes an occasion for memories to evolve around personal objects, thoughts and policed trajectories. The social and economic debts one has

6 The interviews with Harjeet Singh I draw upon in this chapter were been conducted in the period between January 2004 and August 2005. 
accrued become enmeshed with the processes of forming ethical substance. There was the sense of fluctuation and unpredictability when, for instance, I saw Harjeet making calls to brokers to secure a day job or to make sure that enough people would be present for the morning and evening prayers in the gurdwara: 'It is never the same people who come', he said, making it also hard to establish a pattern of participating sangat members. But the point about ethical substance is not merely one of organising routines, of assembling bodies for a religious ritual; it is rather about honing one's own virtues and forming embodied relationship to others. This is where a common notion of sangat among Sikhs is affirmed and where it opens itself to Harjeet's personal memories. The notion is also concerned with the transposition of experiences of sangat to unlikely times and places. For Harjeet, this comprised the daily work in the gurdwara kitchen, the informal interactions and transactions in asylum homes, the conversations and exchange of information and support that we observed occurring daily between those with precarious status. It was through all of these scenarios that a sense of sociality and moral obligation to the other was maintained and that he became reflexive of his circumstances, projects and aspirations to belong.

For Harjeet, the religious routine of nitnem (daily prayers) was at the centre of his reflections connecting sangat to the formation of an ethical self. This entailed taking a bath, then reciting Japji, Jap and the ten savayyas. At sunset, he said, he would always recite Rahiras and Sohila, followed by the Ardas. The turn toward such practice was, in his recollections, directly linked to how ethical substance is formed. As he maintained in our conversations, his 'turn' to stick to a daily routine of recitations, that is, to do proper nitnem, involved a feeling of emancipation. It was relative to roaming around hungry with no roti (bread/food), as another kind of hunger was stilled. But he also expressed a transitive dimension, for he contrasted the rural spaces of his upbringing with his current spiritual quest. 'Initially,' he said, 'I didn't know anything about Sikh religion or the problems our people faced, so at that time my nitnem was just to get up in the morning, say satnaam waheguru [repetitive recitation of the 'name'] for some time, then have breakfast, and continue with my daily chores'. Harjeet did at some point join Sikh missionary reading circles and was part of a group that drove around in the villages to preach. His deliberation on the gurdwara custodian in his village, and the manner in which daily life was enacted, was thus inflected by Sikh reformist ideas. If one listened closely, however, it became apparent that his narrative conveyed sentiments of a political climate of fear and moral resignation in Punjab after a decade of violence and suspicion against Sikhs. What resonated in his remarks were ideas about corporeality and evaluations of embodied practice that were responsive to a particular political climate. He recognised that this climate, 
in other words the material conditions putting constraints on peoples' abilities to act, had an eerie resemblance to the material conditions he later faced as an asylum seeker. As we talked about the issue of where and how to hold nitnem (in solitude or with others) and what to expect from it, Harjeet's thoughts oscillated constantly between a sense of how to maintain psychic integrity and how to perform nitnem with a mind for another:

\footnotetext{
'Today, whatever we do, we seem to do it just for ourselves. According to what Guru says, your own self comes only after taking care of everyone else's wellbeing first. So when I do nitnem it should only have an indirect effect on the self, and most of the time I try. But sometimes in a state of worry, I do think about my own wellbeing first and pray to be relieved of the problem before even thinking about others. But the principle rule is that, everyone, not only oneself - that is, the person who lives with you, your neighbour, someone from the same village, city, country, or on this earth - we should think about the wellbeing of all beings.'
}

He signalled here a form of precarity of self that translates between forms of sociality and ethical orientations (how to maintain other-relatedness as guiding principle) that make it difficult to keep a sense of stability and routine. Surely routine here should not be read as habitual repetition of the same. Harjeet spoke about how keeping up the nitnem was contingent on the place one stayed and the social relationships that enabled or disabled such practice, even if it ought to be otherwise. In the context of living in asylum homes or changing one's residence and status as one moves along in the citizenship regime, it meant that the sense of who belongs to one's sangat constantly changed. Harjeet only recently moved to what he calls a 'decent home', finding time to stay with his girlfriend in Frankfurt once in a while. He told us about the difficulties of living in larger accommodations with people from all over the world gathered together on the same floor and sharing the same bathroom. They were not allowed to buy their own food initially and received non-vegetarian dishes. What to eat and how to keep in physical shape to get up at four in the morning became important issues. People on the floor would smoke and drink and those in the adjacent room complained about the noise. Upholding nitnem in such circumstances became a reflexive practice that was formative of the spatiotemporal conditions of precarity. Spatial arrangements of sociolegal restrictions and classifications, state regulations and surveillance of spaces associated with the sangat, and the difficult journeys of transit and entry all represent processes that interfere and intersect with social and religious imaginaries in such circumstances. Moreover, it is a practice through which the self-in-migration can evaluate their own pursuits and ways of enduring difficult situations, even to the extent that they experience a sense of lost reputation. 
'When I think about how I was coming here, they would sometimes make us sit in the forest for two hours, you know. I would check the time and if it's morning, I would do nitnem. Although there was no way of taking a shower or washing my hands, I had the gurbani memorized, so I would just sit on the ground there and do path. This would bring peace to my mind and even give us some strength, even the people with me.'

Here he talks about a situation that occurred somewhere on his journey to Germany when they had to walk for hours in the forest when trying to make it across the border. There were pressures by others to get on moving but Harjeet, knowing it was a special day in the Sikh (lunar) calendar (sangrand), was firm to keep up with the nitnem and did path:

'I started doing the Barah Maha shabads [hymns by Guru Arjun Dev recited for this purpose]. They got up, one after the other, and started walking, but no one told me to get up. I glanced once and saw them leaving but decided not to leave until the recitation was completed. Because of the delay, we missed the border patrol by just two minutes, so the danger was averted. The others got so happy that, on the way, whenever there was drinking water, they would let me have it first. They would always ask me what I was doing. And whenever it was time to go, they would wait until I had finished. That way they knew they would be safe. It had become such a good thing in their minds. So they liked it that I did this, because whenever I did it, we would not get caught and would not get checked. They felt safe this way. And even after coming here, in my first year or two, the routine was complete. I would do prayers in the morning and evening. Even in the afternoon, during free time, I would do shabad because I am not too fond of television. Even back in India, I never watched television. I would do shabad and memorize gurbani from the Guru Granth Sahib. Sometimes the guys with me would say that I keep on repeating the same thing over and over again and they would insist on me going out with them. But this is how my nature is; even if I am sitting alone all day, I do not get bored. Sometimes it would be hot in the room, and others would tell me to come out, but I thought the more I pray in my spare time, the better it is. Pray or read or memorize more gurbani.'

Whereas this last segment produces a certain aura of piety around him - which he expresses as manoeuvring high risks but also being bestowed with a sense of knowing how to remain unscathed - within the same conversation, he suddenly switched to the fragmentary character of practicing nitnem. Over time 'the system' seemed ruptured and the recognition he received from others shifted to a sense of alienation and isolation.

'But now the situation is different. If I am ever at the gurdwara, or when I am in the room alone, I used to keep a gutka (booklet with the daily prayers) with me before but I don't anymore. I still do nitnem every morning, though I do it a bit late. The 4am thing does not happen anymore, but I try to do it at 6am. The system here is like that. It would get late going to bed at night. Because I don't have any regular work, I have not been able to make it a new routine. It is very hard to keep something going without a system. Now, I never know where I am going, Frankfurt or Hoechst or Offenbach or Giessen. Where to go to sleep and when to wake up? The routine is completely broken now. But still I attempt to do it when I wake up 
in the morning. For example, today I could not complete nitnem. I had to go to the doctor, so I did part of it there. Even if I don't have time to sit and do nitnem, I will do it when I'm on the move. Like in the doctor's office, everybody else was talking but I sat on the chair and did my prayers. I would just complete the time that I had left. If there is no one to talk to you, you can do it going or coming in the train. But the evening routine has remained, I intend to do path before going to sleep. That has been there since the beginning.'

\section{Dukkh: on the material effects of deportability}

Let us now inspect the imbrication of everyday speech with legal categories. For migrants with precarious status, the very process of language acquisition and translation is overburdened with the materiality of language. Court orders, doctor's certificates, police warrants, official notifications, which must appear as opaque to the addressee, are simultaneously felt to be bestowed with the state's power to transform everyday life for better or worse. There are the spoken promises, phone calls to resourceful brokers, references to others in the sangat who might have a reputation and be able to 'do something'. Sometimes, as refugees struggle month by month, there is a sense of being given over that comes to the fore and manifests in the words that are spoken, and how they are spoken. References to Behörde (office), Krankenhaus (hospital), Dolmetscher (interpreter), or waiting for a Schein (certificate or official document) occur as German loanwords in the Punjabi vernacular, signalling ironic self-distancing and the untranslatability of bureaucratic terminology. The Kafkaesque character of the situation was hard to miss, considering the state bureaucracy's notorious suspicion, enacted, for instance, by only granting short temporary permissions and requiring constant reporting, which signalled to those seeking refuge the sense of an absurd transitory existence that Anna Seghers (1951) so nicely portrays in her novel. Yet the transitory and transitive here was entangled with somatic conditions that were deeply troubling, especially for refugees who suffered from posttraumatic stress. One such individual is Gurpreet, known to us through prior contact and, at the time of the research, residing near Cologne. ${ }^{7}$ As a trauma victim his status was contingent on medical certificates that the bureaucracy and courts often dismissed as favouritism (in German legal jargon: 'Gefälligkeitsgutachten'). State bureaucrats are often suspicious of renewed medical certificates, and consider medical professionals cooperating with NGOs as not being impartial enough. On the other hand, asylum policy is precisely designed so that the re-issuing

7 This interview with Gurpreet Singh was conducted on February 19, 2004. 
of medical reports becomes a necessity for the system to work. ${ }^{8}$ To what extent does the regime of health assessments and the re-issuing of short-term residence permits itself produce a discourse on the self in pain? Gurpreet's story below might provide us with some insights.

After we joined Gurpreet for one of his medical consultations, he talked to us about how his efforts to be granted extensions of his stayed deportation affected his sense of self. During our conversation he talked about depression and the strong side effects of the psychiatric drugs the doctor prescribed:

'The medicine should help me sleep because sometimes I think too much and cannot fall asleep. But after taking the pills, I fall asleep and do not feel awake for quite some time, almost up to twelve or fourteen hours. My body feels numb. It becomes like a dead body walking. The other medicine is for the days when I feel too lazy. Taking that the person becomes more active. He has given me these two. When I tell him that it causes problems, he changes it to a different brand.'

'That's why you have grey hair now, whereas you are actually still young?', Khushwant asked him.

'It happens, if you have to think constantly', was Gurpreet’s reply.

His stay of deportation was then being renewed on a monthly basis, which meant that he had to get new certification from the psychiatrist every other month. It is an irony that part of what brought Gurpreet to this kind of impasse was the decision of the officers not to issue work permits any longer. As soon as these permits are issued on a continuous basis, they would give him the legal right of residency. At the point of our interviews, he had been stuck in limbo for three years without permission to work. For considerable periods of time he lined up daily to receive his social assistance payment and get his visa renewed:

'I do not even have permission to go outside of my Kreis (district). There's actually a gurdwara within this district to which we count Düsseldorf, but in my case they have expressed in writing that I cannot leave the city.'

'It is like you are being treated like a criminal who wants to run somewhere', we said.

'I told them', said Gurpreet, 'that I want to do some volunteer work for the sangat, but they didn't even give me permission for that.' [All the letters that were sent through lawyers and community representatives were to no avail.]

'How many years has it been?', we asked. 'And even after having faced so many problems, you are still able to take care of the family? You doing so much even after having so many problems. How do you do this?'

8 There are generally two aspects to consider here: prevailing issues with health from which a person currently suffers (Kriterium der inlandsbezogenen Gesundheitsprobleme) and a risk assessment of health-related issues in the country of origin (erhebliche Gesundheitsgefährdung amounting to Abschiebungshindernisse according to $\S \S 51,53$ AuslG [foreign law]). Both assessments are temporarily valid and are required to be renewed. 


\begin{abstract}
'You know that in our religion, you are not supposed to leave your family behind. I cannot leave my family and children because of my own problem. If I have a personal problem, I can face it and fight it, but that does not mean I should stop taking care of my family', Gurpreet answered. 'And how old are your children?'

'The oldest daughter is 12 or 13. The other was born last August.'

'And when did your wife come?'

'She arrived about four years ago', he confirmed.

'And she gets the same visa as you do?'

'Yes, she and my daughter get the same monthly visas just like me. But my younger son [who is born here] gets a visa for four months. They go by their own will. The director is up to no good. He does whatever he feels is best. He actually said to me that I am the first Indian who he has allowed to stay for this long, otherwise he does not let anyone stay for this long.'
\end{abstract}

'He really said this to you?', we wondered.

'Yes! And when I had seen him initially the first thing he did was to end my work permit. And I said to him that in my religion, we are to work as long as we are able to work with both of our hands and feet. But he said that you are here on political stay, so you do not need to work. We will give you food, and you eat it, that's all.'

'But you still work right?'

'No.'

'We know you worked for some time, right?'

'Yes, I did work before.'

'You did pizza delivery?'

'Yes.'

'How many years have you been here for now?'

'It's almost ten years.'

'Ten years and nothing in return', we remarked. 'You know the law they made that whoever has been here for so many years and who is able to work [...].'

'But yes, that's exactly why they stopped giving me permission to work. If they kept on giving me permission, I would eventually have the right to get my papers. So they killed my right. They stopped it.'

With precarious status, minor transgressions suffice to get people in trouble. Gurpreet was in danger of violating zoning laws of asylum residency when he wanted to participate in religious rituals. Similarly, the bureaucrats might take issue with having a 'wrong address' after he just been relocated from the asylum homes to a social housing unit. Sometimes he had to pretend not to know some of his closest relatives, as their legal status might affect his own. Constant negotiations and endeavours to try to find some way into legality have an impact on wellbeing, especially for those already traumatised. While there are legal mechanisms to incorporate those who stay in limbo for too long, such regulations can, as we have seen, be manipulated. Work permits can be cancelled and deportation slips issued, even if their enforcement is likely to be stopped by medical intervention or through the intervention of lawyers. Gurpreet told us that he once hurt himself 
when the police picked him up to bring him to the Indian embassy in Bonn. He feared they would confirm his identity and deport him.

'I have seen how they kill in Punjab and have tolerated things myself. We had the bodies to bear it before, but not anymore. I used to play kabbadi (a popular contact sport) there before and now I sit around and the body has become soft. When they hit us, it will hurt more than before. The way they hit you is not normal. No one even hits animals in such a manner. So instead of going through that, it is a lot better to kill oneself.'

There were claims that the police wouldn't allow him to return home but instead abandoned him when he started hurting himself with his kirpan (small ceremonial knife typically worn by Khalsa Sikhs) and being admitted to hospital after two bystanders found him in distress. After eight stitches, he was later released, knowing that he could not bring forward any charges. He feared that next time they would arrive with the entire border enforcement team. Meanwhile, deportation procedures would include so-called Abschiebebeobachter, who are appointed by NGOs and who overlook deportation procedures at the airport. ${ }^{9}$ Ten years is a long time for a stayed deportation. Until recently, asylum seekers were only temporarily allowed to work as the permits had to be constantly renewed. Children have the right to go to school but adult refugees spend their days wondering what their future might bring. The fear of being deported is like a shadow that follows these migrants through every single aspect of the chores of everyday life. If you go out to buy groceries, the police might arrest you. The psychiatrist resorts to antidepressants to make you sleep and feel at ease but these make you feel incapacitated. You have a difficult time thinking. It is painful to see things in clear perspective.

In Punjabi, the common reference to such embodied states is $d u k k h$, an idiom that conveys a prolonged form of pain or suffering and expresses something about how negative social transactions result in embodied states of mind. References to dukkh in the Sikh imagination also evoke a state of existence through which subjects acknowledge the idea of Guru's grace. The issue then becomes a question of acceptance and resilience, of seeking explanations in gurbani and of seeking answers and responses to political conditions that cause harm, for the teachings of the Sikh Gurus are not interpreted by these men as some sort

9 This became necessary after several dramatic cases of deportees' deaths received media attention, especially the case of the Sudanese refugee Omar Mohammad Ageeb. See the detailed report: "Bericht an den Innenausschuß des Deutschen Bundestages über den Tod des sudanesischen Staatsangehörigen Aamir Omer Mohamed Ahmed AGEEB bei dessen Rückführung am 28. Mai 1999."

http://www.augenauf.ch/bs/doku/chukwu/ageeb1.htm (last access April 10, 2018). 
of fatalistic acceptance of their current destiny. Considering, for example, Guru Nanak's Malar hymn, dukkh seems multi-layered, capturing the idea of suffering as existential condition, separation from Oneness/the divine that results from ego desires, and ailments that result from unbalanced mind-body relationships. ${ }^{10}$ But comparable with the use of sangat in my participants' responses, the use of vocabularies of pain, suffering and sorrow in Gurpreet's account are of a political register that juxtapose his own somatic state with the injustice of the bureaucratic handling of his claim and the ignorance the state displayed in letting him linger on in a state of depression and posttraumatic stress.

Hence, when we look at how Harjeet and Gurpreet relate to prevailing ideas of ethical conduct in Sikhism, we notice how they invest these ideas with different meanings. Harjeet sees irony in the fact that current circumstances push him constantly into situations where he puts his own interest and ego-desires first. When for example we asked him more about the personal poems he collected, he said: 'Whether I talk about my current situation according to what it says in the Sikh teachings (gurmat) or in my words will be a completely different story,' adding that, 'a gurmukh [someone who has overcome ego and follows the Sikh Guru's example] is never in a state of sadness. One should always remain in charhdi kala. And these poems I read they reflect how time passes, sometimes they express things that make you revolt inside. So I can only read you their key message, not the entire thing'. By contrast, when Gurpreet contemplates dimensions of the self, it is striking how he makes a concession to, on the one hand, a loss of masculinity (having a soft body) and, on the other, a loss of capacity (having nowhere to go), both of which affect his sense of resilience.

\section{Charhdi Kala: fragile and resilient selves}

I have argued that those struggling with a precarious status and the socio-political conditions of expulsion articulate a sense of becoming that does not simply draw on standing vocabularies of culture, rights, and religion. This is because the very foundations of their relationship to others and the quests for making themselves at home are constantly rendered vulnerable. There is a critical mediating element here. The notion of being resilient emerges from within the specific encounters that I have described. But a 'resilient ethos' is often explicitly cited in reference to the principle of charhdi kala, as we just heard from Harjeet. In this concluding

10 For a detailed discussion of the meanings of $d u k k h$ in Sikh theological interpretations, see Pashaura Singh (1998). My reading in this chapter is not oriented towards issues of theodicy. 
section, I want to briefly address such references to the art (kala) or ethos (in the Geertzian sense) of being resilient. As the interactions described in this chapter unfold in a predominantly male world, the question is how such references to a resilient ethos relate to a dominant discourse on Sikh masculinity and heroism. I cannot describe this discourse in detail but it certainly matters in the context of post-1984 identity politics and the focus on militancy and martyrdom. There is also a link in the liturgical context: in the Ardas prayer, charhdi kala is evoked precisely in the context of commemorating all the Sikh martyrs, including those who died during the events of 1984. By including here the story of Rajinder, one of Gurpreet's close acquaintances, I demonstrate that even among those who had identified with pro-separatist politics in Punjab, there is a significant shift in how such an ethos is defined once it is placed in the context of the everyday struggles of those with precarious status. ${ }^{11}$ The story also provides us with an opportunity to look at yet another common genre of speech in contexts where conversations evolve around filing documents and writing letters to various adjudicators. This constitutes an ordinary activity and modality of perseverance but, as we shall see, it also triggers particular representations of the self, as writing to lawyers, receiving letters from doctors and waiting for letters from the courts is part of the very condition that defines the asylum seeker. There is more to be said here about the resilient self when we consider the kind of connections that are being drawn between registers of legal speech and those that appear as magical or transcendent.

We met Rajinder after receiving a call from Gurpreet, who mentioned that his friend couldn't leave the asylum home because he was subject to a deportation order. He had just had his temporary stay renewed for another month. Gurpreet was quite worried about him, so we agreed to go there. Rajinder was an active member of one of the Sikh political youth organisations back in the 1990s and he explained that, as a result, his name appears in Indian police records. When we met him, he had just trimmed his long hair hoping to appear less suspicious upon his return to Delhi. He told us about how a recent 'gurdwara brawl' in which he was implicated was a trigger for the current deportation slip. I want to briefly comment on how he rationalised his interactions with lawyers and judges as a form of resilience and his unwavering trust that some miracle would occur to help resolve the impasse he found himself in. Rajinder is someone who documented his activities in political exile meticulously, from photos taken during protest rallies to the various legal communiqués with lawyers and institutions. He even

11 Interviews with Rajinder Singh were held on February 20 and March 13, 2004. 
wrote letters to the judges who were working on his case. As he sorted through his heavy folder, he took out one such letter to share it with us:

\begin{abstract}
'I just made a request to him [the judge] that said [reads] [...] "I met you three years back and you had told me you would respond in six months and that I could stay here. I asked you to please respond.” I actually wrote him two letters. He then got annoyed [...] When I went on protocol [in the court hearing] he rejected my case. He asked me only a couple of questions. These were not even related to my political status. He asked me really odd questions. For example, he asked, “Tell me what type of help you want from us?” I asked him, if he just meant myself or if he implied all of us. He then confirmed that he meant the plural. So I said that, "we want help from you in the same manner that you helped people from Vietnam or Kosovo in the past. We want that kind of help from your country!" And that's when he answered, "You can forget about that for the next one hundred years." Luckily, there were people sitting with me there, who knew German very well, one of them asked the judge to give him two minutes to speak. So he gave him the two minutes. My friend asked him that as a judge what type of a relationship he has with the government; how it is possible he could say such a thing? He then gave in, saying, "This was not really one of the questions, but I ended up asking it anyway." But he continued to ask me a couple of other such questions. After a while I got a letter that my case had once again been rejected.'
\end{abstract}

At each step of the legal process that involved appeal courts and bureaucrats, Rajinder receives written notice and in turn writes letters, struggling with the material consequences of such legal documents, keeping up a file with all documentations and using all kinds of tactics to avoid receiving a deportation slip. In the process of such interactions and the constant endeavour to manoeuver around illegality and deportability, he displayed resourcefulness and an almost stubborn belief in the potency of his words and letters. I don't suggest here that this forms a paradigmatic way of understanding the resilient self in the context of precarity. It is, however, striking that, whereas Rajinder was the least explicit in claiming spiritual dimensions of Sikhi as a way of self-making, his explicit political struggle pointed to the transcendent in different ways, assuming notions of miracle and magic. I show this with a reference to a well-known activist and petitioner among the Sikh refugees who Rajinder looked up to for his unbroken spirit. Buddha Singh was someone who, despite a disability, continued in his efforts to document human rights violations and in that manner helped Rajinder maintain a sense of hope:

'Buddha Singh has all of the records. December 20 is human rights day, so he told us to distribute a thousand papers each, wherever we live. Even though Buddha Singh has a back problem, he still gave out two thousand papers himself that day. We also handed out papers. If five or six of us handed out a thousand papers, he alone handed out two thousand [...] Let me tell you one more thing. There was a program on television some time ago. Buddha Singh said that initially he was doubtful about stories such as that of Baba Deep Singh, the warrior who fought with his neck cut off. And the same he used to say about the martyrdom of the Panj Pyare [the five individuals originally selected by Guru Gobind Singh for their 
willingness to self-sacrifice to form the nucleus of the Khalsa brotherhood] and how they had their heads cut but still managed to appear unharmed. But then he mentioned to have watched this program on television. In that program they cut a fish into pieces and put the pieces apart. Slowly, as it suffered and suffered, the fish was able attach its parts together. Buddha Singh said he called the producers of the show and asked how that could be possible. They said that it was indeed possible; we did a scientific experiment. So he found that if the fish can be restored into one form, then God can also re-attach Baba Deep Singh's head. So he can tell you quite a lot, Buddha Singh.'

\section{Conclusion}

In each of the three thematic sections above, I have portrayed the ways in which individuals relate to their contemporary struggles with social and legal exclusion through everyday speech, some of which was inflected by registers and genres associated with Sikh gurbani. Although this strategy precluded a more systematic analysis of the German Sikh diaspora as a nascent immigrant community, it could be shown that Sikh refugees, who form a large segment of that population, articulate experiences of migrant precarity not by simply employing religious signifiers but by using these as a modality to reflect existential and political concerns. Within the broader communicative and political context of refugee adjudication that guided the analysis in my two contributions to this publication, this chapter shows that moments of self-making under conditions of prolonged uncertainty were never simply rooted in a given 'belief system' or cultural fabric. On the contrary, each individual struggled with some of the inherited vocabularies as they tried to re-evaluate their own precarity and vulnerability.

When delineating the key conceptual pillars for a theory of religious individualisation, Martin Fuchs $(2015,341)$ argues that such a project needs

to engage with the comparative investigation of self, person, identity and agency and reconceptualise them as contingent processes - processes of self-formation and self-transcendence. Only then will research on individualization allow us to shed more light on the distinction between articulate and inarticulate, explicit and implicit forms of self and identity, elaborating on the tensions between individualization and countervailing tendencies.

This quote relates directly to the ambivalent notion of individualisation that comes to the fore in this chapter, for not only are processes of self-formation precarious by definition, considering that the human rights context is paramount for understanding the predicaments discussed above, but also must we recognise the eroding forces within the broader cultural and social fabric that put stark constraints on religious agency itself. 
The heuristic use of labels, such as 'migrating precarity' above, only partially captures this problematic and runs the risk of a potential complicity in portraying people affected by the loss of home, family, safety and social citizenship, with categories that have become instrumental to social and political regulation. I have argued elsewhere that the general suspicion against racialised religious bodies such as the Sikh body exceeds the specific context of asylum regulation that provided the backdrop for this chapter (Nijhawan 2016). Considering the broader context of targeting Sikh bodies (see Thobani 2012), it is incumbent to read the voices above beyond their idiosyncratic expressions as moments of political critique. Throughout the text, I have also considered questions of religious agency carefully and asked in each instance what to make of 'creative turns' once they appear in my ethnographic setting as 'noteworthy' or maybe, 'too ordinary'. Certainly, the use of the term 'creative' should be broadened beyond capturing historical evidence of 'reinventing tradition' or 're-signifying religious meanings'. Following Martin Fuchs, I consider creativity as an aspect of interactive and inter-subjective processes of encounter and thus have given it a more micro-sociological dimension here with the hope of contributing to a comparative discussion of religious self-formation.

\section{References}

Bakare-Yusuf, Bibi. 2003. 'Rethinking Diasporicity: Embodiment, Emotion, and the Displaced Origin', African and Black Diaspora: An International Journal 1 (2). 147-58.

Bender, Courtney. 2003. Heaven's Kitchen: Living Religion at God's Love We Deliver. Chicago: University of Chicago Press.

Das, Veena. 2007. Life and Words: Violence and the Descent Into the Ordinary. Berkeley: University of California Press.

Fuchs, Martin. 2015. 'Processes of Religious Individualisation: Stocktaking and Issues for the Future', Religion 45 (3). 330-43.

Gonzales, Roberto G. 'Learning to be Illegal Undocumented Youth and Shifting Legal Contexts in the Transition to Adulthood', American Sociological Review 76 (4). 602-19.

Mandair, Arvind-pal Singh. 2009. Religion and the Specter of the West: Sikhism, India, Postcoloniality, and the Politics of Translation. New York: Columbia University Press.

Nijhawan, Michael. 2016. The Precarious Diasporas of Sikh and Ahmadiyya Generations: Violence, Memory, and Agency. New York: Palgrave Macmillan.

Povinelli, Elizabeth A. 2011. Economies of Abandonment: Social Belonging and Endurance in Late Liberalism. Durham, NC: Duke University Press.

Singh, Pashaura. 1999. 'Sikh Perspectives on Health and Suffering: A Focus on Sikh Theodicy.' In: Religion, Health and Suffering, eds. J. R. Hinnells, R. Porter, New York: Kegan Paul International. 111-38.

Singh, Pashaura. 2003. The Bhagats of the Guru Granth Sahib Sikh Self-Definition and the Bhagat Bani. New Delhi: Oxford University Press. 
Standing, Guy. 2016. The Precariat: The New Dangerous Class. New York: Bloomsbury Publishing.

Thobani, Sunera. 2012. 'Racial Violence and the Politics of National Belonging: The Wisconsin Shootings, Islamophobia and the War on Terrorized Bodies', Sikh Formations: Religion, Culture, Theory 8 (3). 281-6.

Waite, L. et al. 2015. 'Precarious Lives: Refugees and Asylum Seekers' Resistance within Unfree Labouring.' ACME: An International Journal for Critical Geographies, 14 (2). 479-91. 